\title{
Erythroid lineage-specific expression and inducibility of the major heat shock protein HSP70 during avian embryogenesis
}

\author{
Sunandita S. Banerii, Kerry Laing, and Richard I. Morimoto \\ Department of Biochemistry, Molecular Biology and Cell Biology, Northwestern University, Evanston, Illinois 60201 USA
}

\begin{abstract}
We have studied the expression of the major heat shock protein HSP70 during maturation of avian erythroid cells. Primitive and definitive erythroid cells were isolated from staged day 3-8 chicken embryos, and the levels of HSP70 mRNA and protein synthesis were examined. The highest levels of HSP70 are detected in polychromatic cells of the day 3-4 primitive erythroid cell. After the initial burst of HSP70 expression the levels of HSP70 mRNA and protein synthesis decline. Although HSP70 is constitutively expressed, neither HSP70 synthesis nor HSP70 mRNA levels were heat shock inducible in primitive red cells. In contrast, definitive red cells respond to heat shock by a 10- to 20-fold increase in HSP70 protein synthesis with little change in HSP70 mRNA levels. These studies reveal that HSP70 expression in erythroid cells is lineage specific, that the levels of HSP70 mRNA are not induced by heat shock, and finally, that the increased expression of HSP70 in definitive cells is due to increased translatability of HSP70 mRNA.
\end{abstract}

[Key Words: Heat shock genes; early development; cell-specific expression; red cells]

Received July 15, 1987; revised version accepted September 1, 1987.

The heat shock or stress response has been widely used in the study of inducible gene expression. Heat shock proteins are also expressed in the absence of stress, either constitutively in a cell cycle-dependent manner or during development and differentiation (for review, see Lindquist 1986). The multiple forms of regulation are reflected in the complex array of cis-acting promoter elements upstream of the vertebrate heat shock genes (Bienz 1986; Morimoto et al. 1986; Wu et al. 1986, 1987). The results of these studies suggest that the function of heat shock proteins is not limited to thermotolerance or protection from adverse environmental stress

The increasing evidence that heat shock proteins are expressed during development includes the small heat shock protein, HSP23, which in Drosophila is ecdysteroid inducible (Ireland and Berger 1982), expressed early in ovarian development (Zimmerman et al. 1983) and in imaginal discs (Cheney and Shearn 1983). Among the early observations that HSP70 was expressed during development was the detection of a 70,000-dalton protein, perhaps HSP70, in the two- to eight-cell stage of mouse embryogenesis (Bensaude et al. 1983). The specific activation of HSP70 during early embryogenesis and the observation that HSP70 is induced in hemin-stimulated human erythroleukemia cell (Singh and Yu 1983) may be related to the cell cycle-specific induction of HSP70 in human cells (Kao et al. 1985; Milarski and Morimoto 1986).

We had shown previously that the HSP70 gene is tran- scribed (Banerii et al. 1984) and translated in avian reticulocytes and that HSP70 accumulates to approximately $1-2 \%$ of the total cell protein in the fully differentiated chicken erythrocyte (Morimoto and Fodor 1984). In this study we examine the expression of the major heat shock protein, HSP70, during avian erythroid differentiation. The synchronous maturation of cells of the chicken erythroid lineage has provided an excellent model system to study the molecular events in early development, such as the onset of $\alpha$ - and $\beta$-globin expression (Engel and Dodgson 1978; Chan 1979; Groudine and Weintraub 1981; Weintraub et al. 1981).

During avian embryogenesis, erythroid precursor cells arise in the early blastoderm from hematocytoblasts which cluster to form blood islands, the sites of red cell proliferation and differentiation (Lucas and Jamroz 1961). Hemoglobin is detected within $32 \mathrm{hr}$ in erythroblasts that mature into early chromatic cells which synthesize high levels of RNA and protein /Cameron and Prescott 1963; Weintraub et al. 1971). By day 5-6, the primitive erythroid cells no longer divide but continue to mature in the circulation (Lucus and Jamroz 1961). Cells of the primitive lineage mature synchronously in the peripheral circulation and are predominant until day 7 of development; thereafter, cells of the definitive lineage are found.

In this study, we show that HSP70 is temporally expressed during the maturation of the primitive erythroid lineage. Despite the constitutive expression of HSP70, 
the primitive erythroid cells are not heat shock responsive at either the transcriptional or translational level, whereas the erythroid cells of the definitive lineage exhibit a significant increase in HSP70 synthesis through a translational control mechanism.

\section{Results}

\section{HSP70 synthesis during avian erythroid maturation}

We examined the expression of major heat shock protein, HSP70, during maturation of the primitive and definitive erythroid lineages in the developing chicken embryo. Red cells were isolated from the peripheral circulation of staged embryos (days 3-7), and the levels of HSP70 synthesis were analyzed by SDS-polyacrylamide gel electrophoresis of ${ }^{35} \mathrm{~S}$-methionine-labeled proteins. Primitive cells of day 3-4 embryos synthesize high levels of a 70,000-dalton protein (Fig. 1) that comigrates on two-dimensional gels with the constitutively synthesized and heat shock-induced HSP70 expressed in adult reticulocytes (Fig. 2; Banerii et al. 1984, 1986; Morimoto and Fodor 1984). The multiple HSP70 isoforms synthesized in heat shocked definitive (day 11) red cells or adult reticulocytes (Fig. 2) correspond to the products of a single HSP70 mRNA species and are likely to be the result of in vivo posttranslational modifications.

As the primitive erythroid cells undergo maturation, the level of HSP70 synthesis declines in parallel with an overall decrease in total cellular protein synthesis (Fig. 1). By day 7 of red cell development, the synthesis of only $\alpha$ - and $\beta$-globin predominates (Fig. 1B). We examined the accumulated levels of HSP70 in red cells from day 3-8 embryos by Western blot analysis using an
anti-HSP70 monoclonal antibody (7.10) provided by $S$. Lindquist and J. Velazquez. The highest levels of HSP70 are found in day 3-4 red cells, in which maximal levels of HSP70 are synthesized; during red cell maturation the accumulated levels of HSP70 decrease (Fig. 1C).

\section{HSP70 mRNA levels in embryonic red cells}

To determine whether the decline in HSP70 synthesis during erythroid maturation was regulated by the abundance of HSP70 mRNA or its translational efficiency, we measured the relative amounts of HSP70 mRNA in cells of the primitive lineage. We first established that the HSP70 gene expressed in primitive erythroid cells corresponded to the cloned chicken HSP70 gene (Morimoto et al. 1986) by S1 nuclease analysis of day 4 total cytoplasmic RNA using a ${ }^{32} \mathrm{P}$-labeled template $(\mathrm{pCl} .8$ digested with HindIII). This provided an accurate measure of mRNA levels and allowed us to exclude the possibility that the developmentally regulated HSP70 gene was distinct from the major heat shock-induced gene.

Total cytoplasmic RNA was isolated from cells of the primitive (day 4) and definitive (day 11) lineages and used for S1 nuclease protection. The size of the S1-protected fragments using cytoplasmic RNA isolated from either erythroid lineage was $1.1 \mathrm{~kb}$, which corresponds to the expected 5'-protected fragments using the cloned chicken HSP70 (Fig. 3). From the relative intensities of the S1-protected fragments it appears that the amount of HSP70 RNA per microgram of total cytoplasmic RNA is nearly equivalent in the primitive and definitive lineages. However, if we compensate for the amount of RNA per cell, which is known to decrease during ery-

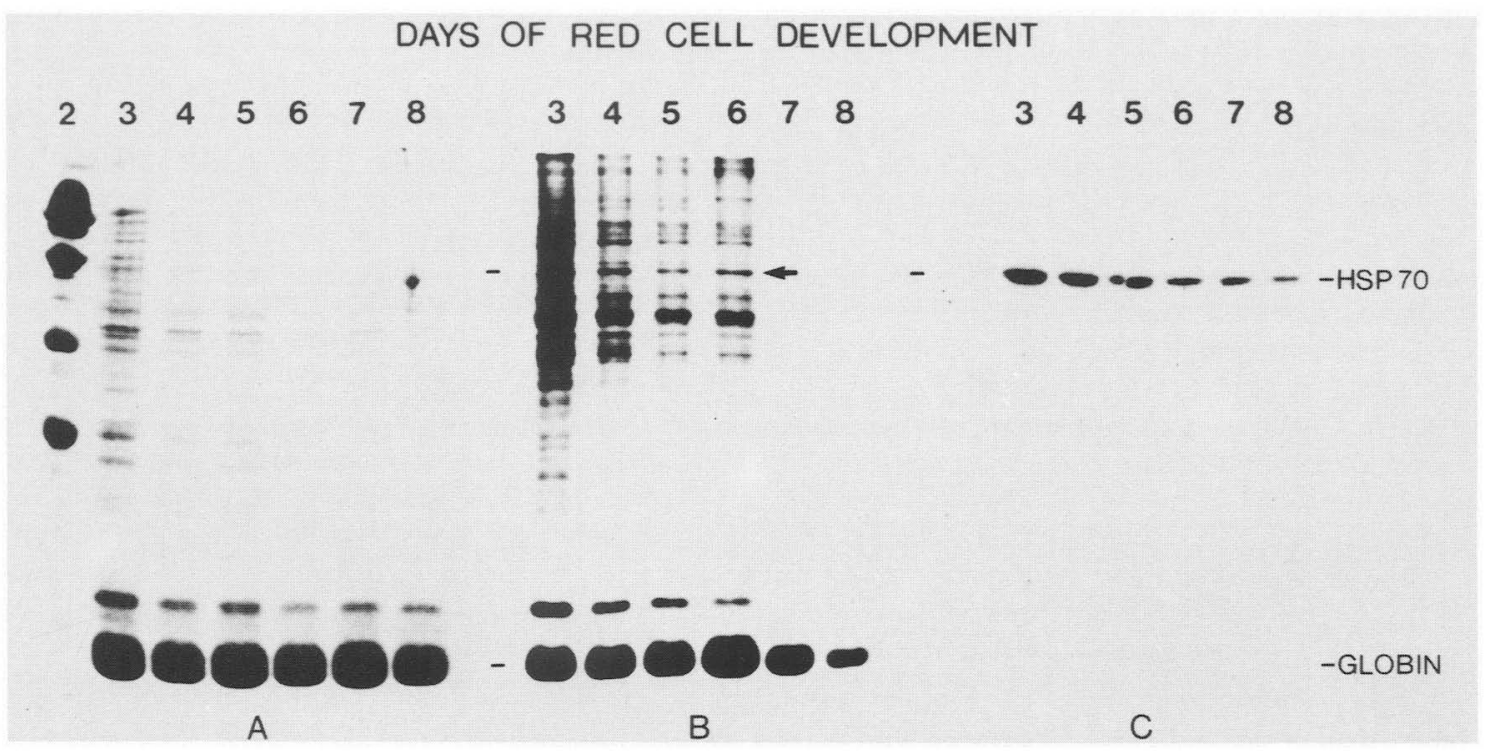

Figure 1. Proteins synthesized and accumulated in day 3-8 embryonic red cells. $(A)$ Coomassie Blue stain of SDS PAGE of proteins from embryonic chicken red cells. Equal numbers of cells $\left(5 \times 10^{6}\right)$ were loaded on each lane. The first lane in panel $A$ are proteins from total day 2 embryonic tissue. (B) Proteins synthesized in day 3-8 embryonic red cells. ${ }^{35}$ S-methionine-labeled proteins from equal numbers of red cells were analyzed by SDS PAGE and fluorography. $(C)$ Western blot analysis of identical gel as in panel $A$. Proteins were transferred onto nitrocellulose and probed with the anti-HSP70 antibody 7.10 . The electrophoretic positions of HSP70 and globin are indicated. 


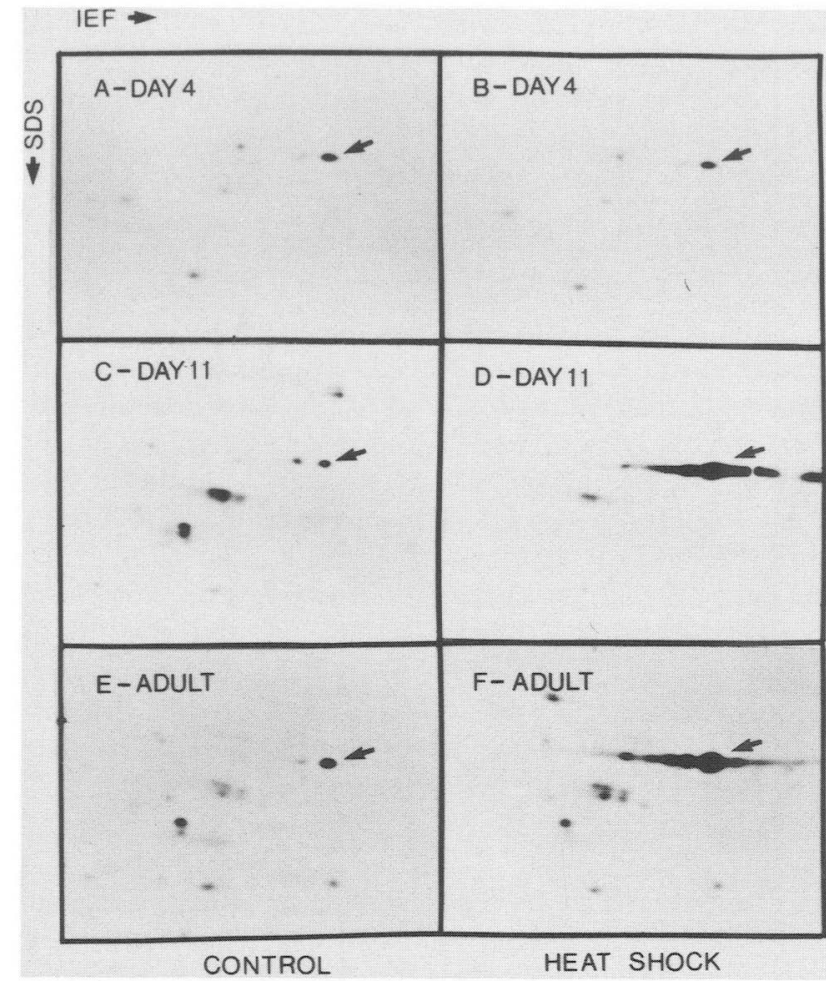

Figure 2. Two-dimensional gel electrophoresis of proteins synthesized in chicken erythroid cells. Red cells were incubated at control $\left(37^{\circ} \mathrm{C}\right)$ or heat shock $\left(43^{\circ} \mathrm{C}\right)$ temperature for 30 min and pulse labeled with ${ }^{35} \mathrm{~S}$-methionine. The radiolabeled proteins were separated by isoelectric focusing linear gradients (pH 5-7) followed by SDS PAGE. $(A, B)$ Day 4 primitive red cells; $(C, D)$ day 11 definitive red cells; $(E, F)$ adult reticulocytes. The location of HSP70 is indicated.

throid maturation (Small and Davies 1972), the levels of HSP70 mRNA in day 4 cells are approximately five-fold higher than in day 11 cells or in adult reticulocytes.

To examine the levels of HSP70 mRNA during maturation of the primitive erythroid cell, total cytoplasmic RNA was isolated from day 3 to day 8 cells for RNA dot blot analysis. We compared the levels of HSP70 mRNA in maturing cells to the relative levels of two red cellspecific transcripts, $\beta$-globin and histone $\mathrm{H} 5$, used as a reference. Total cytoplasmic RNA was isolated, denatured, and bound to nitrocellulose in triplicate, and the filters were hybridized to the respective ${ }^{32} \mathrm{P}$-labeled probes. The autoradiograms were quantitated and normalized for equal amounts of total RNA using standards. During erythroid maturation the amount of $\beta$ globin mRNA increases dramatically between days 5 and 7 (Fig. 4; Engel and Dodgson 1978). Meanwhile, the relative levels of HSP70 and histone H5 mRNAs, although initially high in day 3 red cells, decrease during maturation (Fig. 5). These results are consistent with the expression of histone $\mathrm{H} 5$, which is present in the maturing red cell at the transition from the primitive to the definitive population (Moss et al. 1973).

The decrease in HSP70 mRNA levels in differentiating cells is also reflected in the decreased synthesis of HSP70 observed in Figure 1. The temporal change in the levels of HSP70 mRNA and protein synthesis during maturation of the primitive erythroid lineage suggests that HSP70 expression is developmentally regulated in red cells.

\section{Lineage-specific regulation of the heat shock response}

To determine whether red cells of the primitive and definitive lineages were heat shock responsive, cells from day 4 and day 11 chicken embryos and from adult anemic hens were heat shocked and the levels of HSP70 mRNA measured. We compared the level of HSP70 mRNA in control and heat-shocked erythroid cells to control and heat-shocked MSB cells (Marek's disease virus-transformed chicken lymphoblastoid line) and liver and brain tissues from day 11 embryos. Comparison of HSP70 expression in control or heat-shocked primitive red cells by $\mathrm{S} 1$ analysis reveals that the levels of HSP70 RNA did not increase following heat shock whereas the levels of HSP70 RNA increased less than two-fold in heat-shocked definitive cells and adult reticulocytes (Fig. 3). Thus, cells from both embryonic erythroid lineages are not heat shock responsive at the

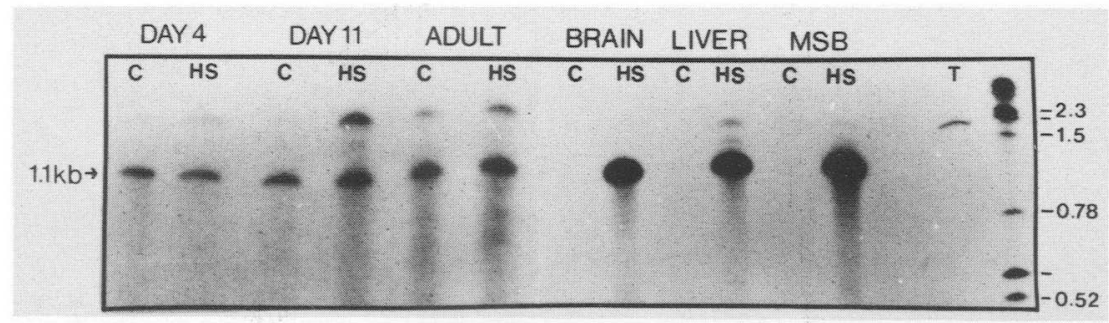

Figure 3. Levels of HSP70 mRNA in chicken erythroid, lymphblast, liver, and brain cells and tissues. Red cells or embryonic tissues were maintained at control and heat shock temperatures, and RNA was isolated for $\$ 1$ nuclease protection using an HSP70 gene probe. The protected fragments were analyzed on $4 \%$ polyacrylamide gels containing $8 \mathrm{M}$ urea. Sixty micrograms of control $\mid \mathrm{c}$ ) and heat shock (HS) RNA from day 4 and day 11 embryonic red cells $\left(5 \times 10^{7}\right.$ and $1 \times 10^{7}$ cells $)$ and poly $(A)^{+}$RNA from control or heat-shocked adult reticulocytes from $2 \times 10^{8}$ cells were analyzed in the annealing reactions. RNA from control or heat-shocked day 11 liver and brain was also analyzed, along with RNA from control or heat-shocked MSB cells. The last two lanes contain the annealing reaction containing only the tRNA carrier and a $1 \times 100$ dilution of the template. The exposure to X-ray film of the brain, liver, and MSB samples was $12 \mathrm{hr}$ versus 10 days for the erythroid samples. 


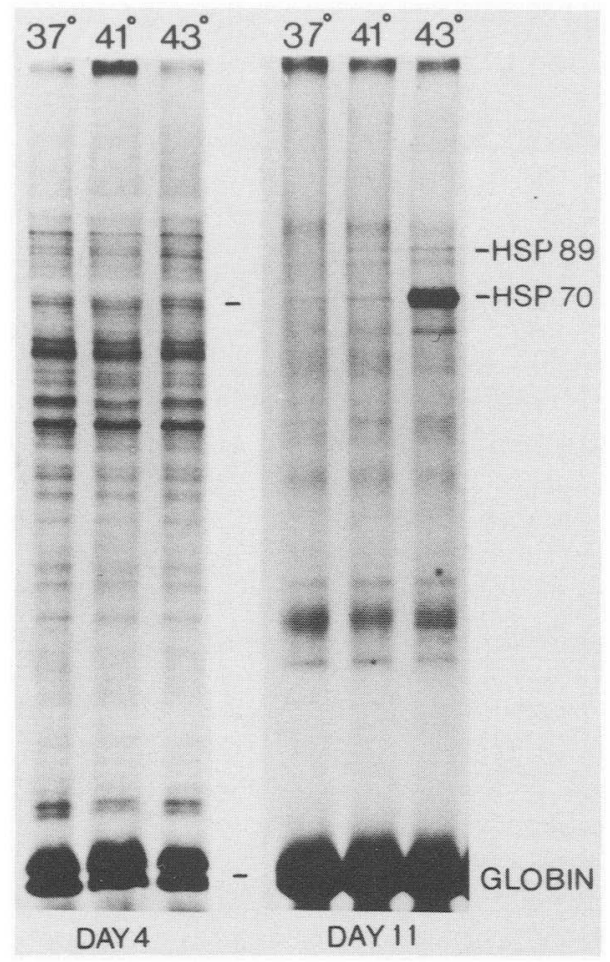

Figure 4. Comparison of the heat shock response in primitive and definitive red cells. Whole fertilized eggs were incubated at $37^{\circ} \mathrm{C}, 41^{\circ} \mathrm{C}, 43^{\circ} \mathrm{C}$ for $2.5 \mathrm{hr}$. The embryos were labeled in situ with ${ }^{35} \mathrm{~S}$-methionine for $1 \mathrm{hr}$ at $37^{\circ} \mathrm{C}$. The red cells were isolated and the pattern of protein synthesis in day 4 or day 11 red cells analyzed by SDS PAGE and fluorography. Equal amounts of radioactivity $\left(5 \times 10^{4} \mathrm{cpm}\right)$ were loaded onto each lane. The positions of HSP89, HSP70, and globin are indicated.

mRNA level, a result that is similar to previous studies using adult reticulocytes in which heat shock only slightly increases HSP70 mRNA levels (Banerii et al. 1984).

The lack of a heat shock-induced increase in HSP70 mRNA in definitive cells is in striking contrast to the lymphoblastoid (MSB) cells, brain or liver tissues, in which HSP70 mRNA levels are weakly detected in control tissues and induced 20-50-fold following heat shock (Fig. 3). As shown by comparison of the autoradiographic exposures, the level of HSP70 mRNA induced by heat shock of liver and brain tissues is approximately 100 -fold greater than that constitutively expressed or heat shock induced in erythroid cells. Therefore, it is unlikely that the lack of a heat shock response in erythroid cells is due to the unusually high levels of HSP70 expression. These results reveal that regulation of the heat shock response is tissue specific (Banerii et al. 1984, 1986; Morimoto and Fodor 1984).

Although the levels of HSP70 mRNA do not increase during heat shock, HSP70 synthesis increases greater than 20-fold in adult reticulocytes. To ask whether the heat shock response in the embryonic lineages was regulated at the level of translational control, we examined the levels of HSP70 protein synthesis in heat-shocked primitive and definitive red cells. We were concerned that the manipulations required to isolate red cells may cause sufficient stress for the induction of heat shock genes regardless of the temperature of incubation. Such an occurrence may produce results that could be interpreted as a high constitutive but uninducible level of HSP70 expression. Therefore, whole fertilized eggs at day 4 , corresponding to the primitive erythroid cell, and at day 11 , corresponding to the definitive cell, were incubated at control $\left(37^{\circ} \mathrm{C}\right)$ or heat shock temperatures $\left(41^{\circ} \mathrm{C}\right.$ and $\left.43^{\circ} \mathrm{C}\right)$. Proteins were labeled in situ by injection of ${ }^{35} \mathrm{~S}$-methionine and the red cells isolated for analysis by SDS-PAGE.

The results of in situ heat shock and labeling of primitive and definitive red cells shown in Figure 5 are identical to our previous results when the cells were isolated, incubated, and labeled in vitro (Fig. 2). Therefore, basal HSP70 expression is unlikely to be due to accidental stress and is representative of the normal cellular state. HSP70 is constitutively synthesized in primitive red cells is in contrast to the definitive cells in which HSP70 synthesis is induced 15 -fold following $43^{\circ} \mathrm{C}$ heat shock (Fig. 5B).

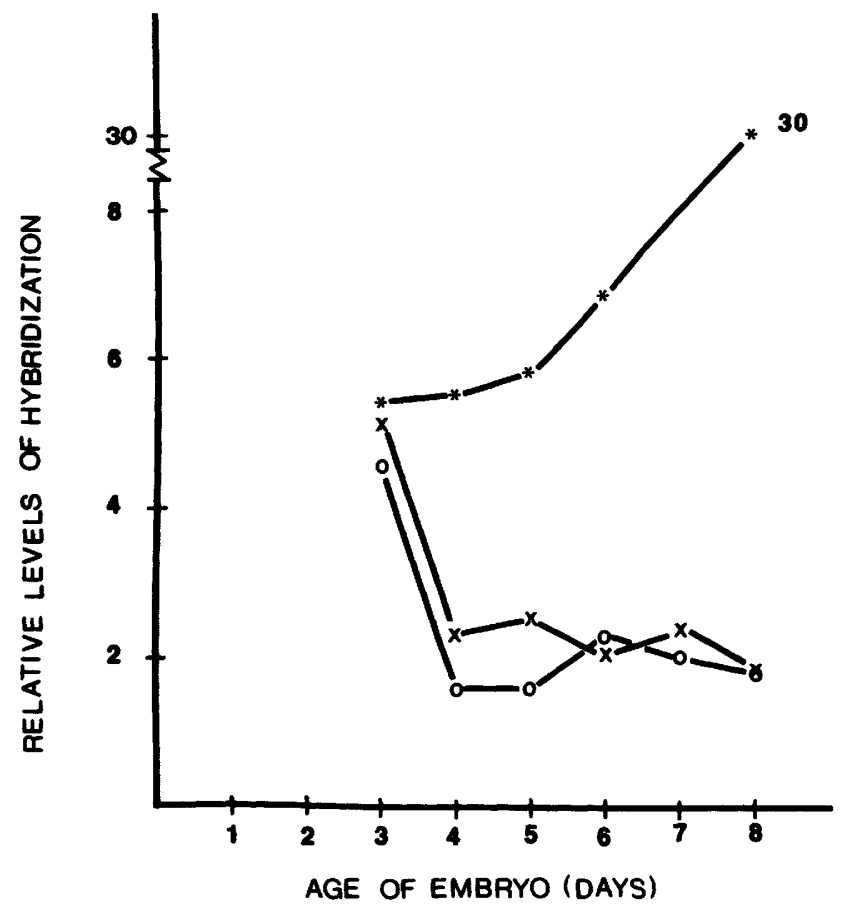

Figure 5. Quantitation of HSP70, histone H5, and $\beta$-globin mRNAs during maturation of primitive red cells. Two micrograms of RNA from day 3-8 embryonic red cells was denatured with formaldehyde and spotted in triplicate onto nitrocellulose. The filters were hybridized with ${ }^{32} \mathrm{P}$-labeled DNA for chicken HSP70, pC1.8 (Morimoto et al. 1986)(x), chicken histone H5, p541 (Ruiz-Vazquez and Ruiz-Carrillo 1982) (o), or the chicken $\beta$-globin gene, $\mathrm{p} \beta 1 \mathrm{BR} 15$ (Dolan et al. 1983) ( $\left.{ }^{\star}\right)$. One filter was rehybridized with a ${ }^{32} \mathrm{P}$-labeled ribosomal DNA, and the results were used to normalize for RNA levels. Autoradiograms were scanned by densitometry (Transydine) to quantitate changes in mRNA levels during embryonic erythroid maturation. Filters probed with pC1.8 or p541 were exposed for 5 days. The $\beta$ globin-probed filter was exposed for $12 \mathrm{hr}$. 
The heat shock response in definitive cells appears to be regulated at the translational level, resulting in increased HSP70 synthesis without a corresponding increase in HSP70 mRNA levels. The primitive cells are unresponsive at both the transcriptional and translational levels.

\section{Discussion}

In this study we demonstrate that expression of the major heat shock protein HSP70 is developmentally regulated during chicken erythropoiesis. Primitive red cells from day 3 embryos synthesize high levels of HSP70; during maturation the levels of HSP70 synthesis decline. Although HSP70 is expressed in cells of both primitive and definitive erythroid lineages, only the definitive cells induce HSP70 synthesis following heat shock. However, the heat shock response in definitive cells occurs at the level of translational control, an uncommon but not unprecedented observation (Bienz and Gurdon 1982). In primitive cells, HSP70 mRNA levels are not induced nor is the efficiency of translation of the pre-existing HSP70 mRNA increased during heat shock.

Our studies on red cell expression extend observations that have detected HSP70 or HSP70-related proteins in early mouse or sea urchin embryonic development (Roccheri et al. 1981; Bensaude et al. 1983; Morange et al. 1984; Heikkila et al. 1985, 1986; Hahnel et al. 1986; Kothary et al. 1987). The interpretation of many of these studies has been complicated by the lack of well-characterized gene probes, which has made it difficult to distinguish among the HSP70-related proteins. Another difficulty that has complicated the analysis of gene-specific expression is that the HSP70 gene is present in multiple copies in yeast, rodent, or human cells (Ignolia et al. 1982; Moran et al. 1982; Harrison et al. 1987). In chicken cells this issue is not a concern as the HSP70 gene is present at a single copy per genome (Morimoto et al. 1986). Therefore, the multiple forms of regulation, for example lineage-specific red cell developmental expression and heat shock induction, can be analyzed by dissection of the cloned chicken HSP70 gene.

The developmental expression and accumulation of high levels of HSP70 in the terminally differentiated erythrocyte is consistent with a suggested role for this heat shock protein with damaged or denatured proteins (Pelham 1985). During erythroid maturation the red cell nucleus condenses, DNA and RNA synthesis is repressed, and many of the intercellular organelles and proteins are degraded as the cell progresses toward its terminal role as a membranous vesicle for hemoglobin (Small and Davies 1972; Cameron and Prescott 1963; Campbell et al. 1971; Williams 1972a,b; Ringertz and Bolund 1974). HSP70 is also developmentally expressed and synthesized at high levels during spermatocyte maturation (Krawczk et al. 1987; Zakeri and Wolgemuth 1987). It is interesting to note that erythrocytes (in avians) and spermatocytes represent highly differentiated cells which share common terminal events such as nuclear condensation and generalized biosynthetic arrest and express high levels of HSP70. HSP70 or HSP70- related proteins have been implicated recently in recycling of the transferrin receptor in sheep reticulocytes (Davis et al. 1986). Indeed, injection of denatured proteins into cells is sufficient to activate HSP70 expression (Anathan et al. 1986). The relationship between stress proteins and proteolysis is further supported by identification of ubiquitin as a heat shock protein in chicken cells (Bond and Schlesinger 1985) and the lon protease as a heat shock protein in E. coli (Goff and Goldberg 1985). Perhaps the accumulation of high levels of HSP70 in red cells is a response to the increased levels of proteins that accumulate and are degraded in the process of terminal differentiation.

There is increasing evidence that heat shock responsiveness is not universal, a result that suggests that either the heat shock activator protein, factors that regulate its activity, or other components of the heat shock transcription apparatus are not ubiquitous. In Drosophila oocytes, HSPs 83,28 , and 26 are constitutively expressed and HSPs 70, 23, and 22 are neither expressed nor heat shock inducible (Zimmerman et al. 1983). The normal repertoire of HSPs is also not inducible in Drosophila embryos (Graziosi et al. 1980) and sea urchin embryos until the 64-128 cell stage (Roccheri et al. 1981), in Xenopus embryos until gastrulation (Heikkila et al. 1985), the one-cell stage of the mouse embryo (Bensaude and Morange 1983), and the growing root tips of Zea (Cooper et al. 1984). In many of these examples, the heat shock response is absent in an early developmental stage and acquired at a later stage. This suggests that an essential component of the heat shock transcriptional apparatus is developmentally regulated.

Our studies on HSP70 expression and heat shock inducibility in red cells reveal that red cells and lymphoid cells have distinct mechanisms of response; the increased synthesis of HSP70 in definitive cells is due to preferential translation whereas lymphoid cells are heat shock responsive at the transcriptional level (Banerii et al. 1986). The absence of both forms of HSP70 gene expression in primitive cells suggests that these regulatory mechanisms may be cell-specific forms of expression.

\section{Materials and methods}

Chicken embryos, cells: isolation and metabolic labeling

Fertilized eggs were purchased Sharp Sales (Wheaton, Illinois) and incubated in a Humidaire hatchery at $38^{\circ} \mathrm{C}$ with automatic rotation. The embryos were developmentally staged according to Lillie (Hamilton 1952). Red cells were obtained from the blood islands or from the main blood vessels from day 3-day 8 embryos. Typically, $51 / 2$ dozen eggs were needed for the day 3 red cell experiments, with decreasing amounts of eggs needed on subsequent days. The red cells were washed free of serum and yolk, resuspended in methionine-free DME, and labeled with $50 \mu \mathrm{Ci} / \mathrm{ml}^{35} \mathrm{~S}$-methionine for $2 \mathrm{hr}$ at $37^{\circ} \mathrm{C}$.

Whole fertilized eggs required $2 \mathrm{hr}$ to attain heat shock temperatures as measured with a thermistor probe and digital thermometer (Markson, Model 7001). After an additional $30 \mathrm{~min}$ at each temperature, the egg shell and membrane were removed and $250 \mu \mathrm{Ci}$ of ${ }^{35} \mathrm{~S}$-methionine was injected into the allantoic fluid adjacent to the day 4 embryos or directly into the day 11 
embryos (Voellmy and Bromley 1982). The embryos were returned to $37^{\circ}$ for $2 \mathrm{hr}$, the red cells or tissues were removed, washed with PBS, and frozen in dry-ice ethanol.

Chicken lymphoblastoid (MSB) cells (Akiyama and Kato 1974) were maintained in mid-log phase by continuous culture at $37^{\circ} \mathrm{C}$ in $5 \% \mathrm{CO}_{2}$ in RPMI- 1640 media containing $5 \%$ calf serum and $1 \%$ chicken serum.

\section{Analysis of proteins}

Tissue samples and red cells were sonicated in SDS sample buffer (Laemmli 1970) and boiled. The level of radioisotope incorporation into protein was determined by trichloroacetic acid (TCA) precipitation of lysates treated with $0.5 \mathrm{M} \mathrm{NAOH}$. Total cell proteins were analyzed on $12.5 \%$ SDS-PAGE using a Trisglycine buffer (Blattler et al. 1972) and fluorographed (Laskey and Mills 1974). Proteins were also analyzed by two-dimensional gel electrophoresis (O'Farrell 1975) using isoelectric focusing gels ( $4 \%$ polyacrylamide) and ampholines to form linear gradients of $\mathrm{pH} 5-7$.

For Western blot analysis, unlabeled cell lysates were separated by SDS-PAGE; the gel was soaked in transfer buffer and electrophoretically transferred to nitrocellulose (Burnette 1981). The filters were incubated with the nonspecific blocking agent BSA, followed by incubation with the anti-HSP70 antibody 7.10 (Munro and Pelham 1986; Velazquez et al. 1986) and ${ }^{125}$ I-labeled goat anti-mouse antibody.

\section{RNA isolation and analysis}

RNA was isolated using a modified guanidine thiocyanate procedure (Chirgwin et al. 1979) followed by hot phenol extraction (Feramisco et al. 1982). Cell pellets were homogenized in at least 5 volumes of buffer containing $4 \mathrm{M}$ guanidine thiocyanate, $50 \mathrm{~mm}$ Tris- $\mathrm{HCl}$ (pH 7.6), $10 \mathrm{mM}$ EDTA, $1 \%$ (vol/vol) 2-mercaptoethanol, and $2 \%(\mathrm{wt} / \mathrm{vol})$ sarkosyl. Equal volumes of hot phenol $\left(60^{\circ} \mathrm{C}\right), \quad 0.1 \mathrm{M}$ sodium acetate $(\mathrm{pH} \quad 5.5)$, and chloroform : isoamyl alcohol $(24: 1)$ were added. The RNA was extracted at $60^{\circ} \mathrm{C}$ for $10 \mathrm{~min}$, chilled on ice, and the phases were separated by centrifugation. The aqueous phase was re-extracted twice with phenol and chloroform : isoamyl alcohol and once with chloroform at room temperatue, followed by precipitation with 2.5 volumes of ethanol. Total poly $(\mathrm{A}){ }^{+}$was purified using oligo(dT) cellulose chromatography (Aviv and Leder 1972 .

Dot blot analysis was performed using total cytoplasmic RNA isolated by the rapid lysis procedure described previously (Banerii et al. 1986). S1 nuclease protection analysis (Berk and Sharp 1977) was performed using a 5'-labeled DNA probe prepared from the digestion of $\mathrm{pCl} .8$ (Morimoto et al. 1986) with HindIII followed by dephosphorylation and kinasing in the presence of ${ }^{32} \mathrm{P}-\mathrm{ATP}$ and polynucleotide kinase. This DNA probe spans the region of the gene that contains the transcription start site. The RNA was annealed to the ${ }^{32} \mathrm{P}$-labeled probe in $80 \%$ formamide, $400 \mathrm{~mm} \mathrm{NaCl}, 40 \mathrm{~mm}$ PIPES, and $2 \mathrm{~mm}$ EDTA at $53^{\circ} \mathrm{C}$ for $4-12 \mathrm{hr}$, after which the RNA-DNA duplex was subjected to S1-nuclease digestion in the presence of $3 \mathrm{~mm}$ $\mathrm{ZnSO}_{4}, 50 \mathrm{~mm}$ sodium acetate, $225 \mathrm{~mm} \mathrm{NaCl}$, and $400 \mathrm{u} / \mathrm{ml} \mathrm{s} 1$ nuclease (Boehringer Mannheim, Amersham).

\section{Acknowledgments}

We thank N.G. Theodorakis, B. Wu, and J.D. Engel for many helptul discussions and Susan Lindquist for generously providing antibody 7.10. These studies were supported by grants from the National Institutes of Health, a Faculty Research
Award from the American Cancer Society (FRA313) to R.M., and an AMOCO Graduate Fellowship to S.S.B.

\section{References}

Akiyama, Y. and S. Kato. 1974. Two lines from lymphomas of Marek's disease. Biken I. 17: 105-116.

Ananthan, T., A.L. Goldberg, and R. Voellmy. 1986. Abnormal proteins serve as eukaryotic stress signals and trigger the activation of heat shock genes. Science 232: 522-524.

Aviv, H. and D. Leder. 1972. Purification of biologically active globin messenger RNA by chromatography on oligothymidylic acid. Proc. Natl. Acad. Sci. 69: 1408-1412.

Banerji, S.S., N.G. Theodorakis, and R. Morimoto. 1984. Heat shock induced translational control of HSP70 and globin synthesis in chicken reticulocytes. Mol. Cell. Biol. 4: 24372448.

Banerii, S.S., K.L. Berg, and R.I. Morimoto. 1986. Transcriptional and post transcriptional regulation of avian HSP70 gene expression. J. Biol. Chem. 261: 15740-15745.

Bensaude, O. and M. Morange. 1983. Spontaneous high expression of heat shock protein in mouse embryonal carcinoma cells and ectoderm from day 8 mouse embryo. EMBO $J$. 2: 173-177.

Bensaude, O., C. Babinet, M. Morange, and F. Jacob. 1983. Heat shock proteins, first major products of zygotic gene activity in mouse embryo. Nature 305: 331-333.

Berk, A.K. and P. Sharp. 1977. Sizing and mapping of early adenovirus mRNA by gel electrophoresis of $\mathrm{S} 1$ endonuclease digested hybrids. Cell 12: 721-732.

Bienz, M. 1986. A CCAAT box confers cell-type specific regulation on the Xenopus HSP70 gene in oocytes. Cell 46: 10371042.

Bienz, M. and J. Gurdon. 1982. The heat shock response in Xenopus is controlled at the translational level. Cell 29: $811-819$.

Blattler, D.P., F. Garner, K. VanSlyke, and A. Bradley. 1972. Quantitative electrophoresis in polyacrylamide gels of 2-40\%. J. Chromatogr. 64: 147-155.

Bond, U. and M.J. Schlesinger. 1985. Ubiquitin is a heat shock protein in chicken embryo fibroblasts. Mol. Cell. Biol. 5: 949-991.

Burnette, W.N. 1981."Western blotting": Electrophoretic transfer of proteins from sodium dodecyl sulfate-polyacrylamide gels to unmodified nitrocellulose and radiographic detection with antibody and protein. Anal. Biochem. 112: 195-203.

Cameron, I.L. and D.M. Prescott. 1963. RNA and protein metabolism in the maturation of the nucleated chicken erythrocyte. Exp. Cell Res. 30: 609-612.

Campbell, G., M. Le, H. Weintraub, B.H. Mayall, and H. Holtzer. 1971. Primitive erythropoesis in early chick embryogenesis. II. Correlation between hemoglobin synthesis and the mitotic history. J. Cell Biol. 50: 669-681.

Chan, L.-NL. 1979. Regulation of embryonic hemoglobin in chickens. In Conference on cellular and molecular regulation of hemoglobin switching. (ed. G. Stamatoyannopoulos and A.W. Nienhaus), pp. 693-702. Grune and Stratten, New York.

Cheney, C.M. and A. Shearn. 1983. Developmental regulation of Drosophila imaginal disc proteins: Synthesis of a heat shock protein under non-heat shock conditions. Dev. Biol. 95: $325-330$.

Chirgwin, J., A.E. Przybyla, R.I. MacDonald, and W.J. Rutter. 1979. Isolation of biologically active ribonucleic acid from 
Banerji et al.

sources enriched in ribonuclease. Biochemistry 18: 52945299.

Cooper, P., T.-H. Ho, and R.M. Hauptmann. 1984. Tissue specificity of the heat-shock response in maize. Plant Physiol. 75: 431-441.

Davis, J.Q., D. Dansereau, R.M. Johnstone, and V. Bennett. 1986. Selective externalization of an ATP-binding protein, structurally related to the clathrin-uncoating ATPase/Heat shock protein in vesicles containing terminal transferin receptors during reticulocyte maturation. I. Biol. Chem. 263: 15368-15371.

Dolan, M., J.B. Dodgsen, and J.D. Engel. 1983. Analysis of the adult chicken $\beta$-globin gene: Nucleotide sequence of the locus, microheterogeneity at the $5^{\prime}$-end of the $\beta$-globin mRNA and aberrant nuclear species. I. Biol. Chem. 258: 3983-3990.

Engel, J.D. and J.B. Dodgson. 1978. Analysis of the adult and embryonic chicken globin genes in chromosomal DNA. $I$. Biol. Chem. 253: 8239-8246.

Feramisco, J.R., J.E. Smart, K. Burridge, D.M. Helfmann, and G.P. Thomas. 1982. Co-existence of vinculin and a vinculin-like protein of higher molecular weight in smooth muscle. J. Biol. Chem 257: 11024-11031.

Goff, S.A. and A.L. Goldberg. 1985. Production of abnormal proteins in $E$. coli stimulates transcription of lon and other heat shock genes. Cell 41: 587-595.

Graziosi, G., F. Micali, R. Marzarc, F. diChistini, and A. Savoni. 1980. Variability of response of early Drosophila embryos to heat shock. J. Exp. Zool. 214: 141-145.

Groudine, M. and H. Weintraub. 1981. Activation of globin genes during chicken development. Cell 24: 393-401.

Hahnel, A.C., D.J. Gifford, T.T. Heikkila, and G.A. Schultz. 1986. Expression of the major heat shock protein (HSP70) family during early mouse embryo development. Teratog. Carcinog. Mutagen. 6: 493-510.

Hamilton, H.L. 1952. Lillie's Development of the chick: An introduction to embryology. Holt, Rinehart, and Winston, New York.

Harrison, G.S., H.A. Drabkin, F.-T. Kao, J. Hartz, I.M. Hart, E.H.Y. Chu, B.J. Wu, and R.I. Morimoto. 1987. Chromosomal location of human genes encoding major heat-shock protein HSP70. Somatic Cell Mol. Genet. 13: 119-130.

Heikkila, J.J., M. Kloc, J. Bury, G.A. Schultz, and L.W. Browder. 1985. Acquisition of the heat shock response and thermotolerance during early development of Xenopus laevis. Dev. Biol. 107: 483-489.

Heikkila, J.J., L.W. Browder, L. Gedami, R.W. Nickells, and G.A. Schultz. 1986. Heat shock expression in animal embryonic systems. Can. J. Genet. Cytol. 28: 1093-1105.

Ignolia, T.D., M.R. Slater, and E.A. Craig. 1982. Saccharomyces cerevisiae contains a complex multigene family related to the major heat-shock inducible gene of Drosophila. Mol. Cell. Biol. 2: 1388-1398.

Ireland, R.C. and E.M. Berger. 1982. Synthesis of low molecular weight heat shock peptides stimulated by ecdysterone in a cultured Drosphila cell line. Proc. Natl. Acad. Sci. 79: 855859.

Kao, H.-T., O. Capasso, N. Heintz, and J.R. Nevins. 1985. Cell cycle control of the human hsp70 gene: Implications for the role of a cellular E1A-like function. Mol. Cell. Biol. 5: 628633.

Kothary, R., M.D. Perry, L.A. Moran, and J. Rossant. 1987. Cell-lineage-specific expression of the mouse HSP68 gene during embryogenesis. Dev. Biol. 121: 342-348.

Krawczk, Z., J. Wismewski, and E. Bleslada. 1987. A HSP70 related gene is constitutively expressed highly in testes of rat and mouse. Mol. Biol. Rep. (in press).

Laemmli, U.K. 1970. Cleavage of the structural proteins during the assembly of the head of bacteriophage T4. Nature 282: $249-256$.

Laskey, R.A. and A.D. Mills. 1974. Quantitative film detection of ${ }^{3} \mathrm{H}$ and ${ }^{14} \mathrm{C}$ in polyacrylamide gels by fluorography. Eur. $J$. Biochem. 56: 335-341.

Lindquist, S. 1986. The heat shock response. Annu. Rev. Biochem. 55: 1151-1191.

Lucas, A.M. and C. Jamroz. 1961. Atlas of Avian Hematology. US Dep. Agric. Monogr. Washington, DC.

Milarski, K.L. and R.I. Morimoto. 1986. Expression of human HSP70 during the synthetic phase of the cell cycle. Proc. Natl. Acad. Sci. 83: 9517-9521.

Moran, L.A., M. Chawin, M.E. Kennegy, M. Korri, and D.G. Lowe. 1982. The major heat shock protein (hsp70) gene family: Related sequences in mouse, Drosophila, and yeast. Can. J. Biochem. Cell Biol. 51: 488-499.

Morange, M., A. Diu, O. Bensaude, and C. Babinet. 1984. Altered expression of heat shock proteins in embryonal carcinoma and mouse early embryonic cells. Mol. Cell. Biol. 4: 730-735.

Morimoto, R. and E. Fodor. 1984. Cell specific expression of heat shock proteins in chicken reticulocytes and lymphocytes. I. Cell Biol. 99: 1316-1323.

Morimoto, R., C. Hunt, S.-Y Huang, K.L. Berg, and S.S. Banerii. 1986. Organization, nucleotide sequence and transcription of the chicken HSP70 gene. I. Biol. Chem. 261: 1269212699.

Moss, B., W.G. Joyce, and V.M. Ingram. 1973. Histones in chick embryonic erythropoesis. J. Biol. Chem. 246: 1025-1031.

Munro, S. and H.R.B. Pelham. 1986. An HSP70-like protein in the ER: Identity with the $78 \mathrm{kD}$ glucose regulated protein and immunoglobulin heavy chain binding protein. Cell 46: $291-300$.

O'Farrell, P.H. 1975. High resolution two dimensional electrophoresis of proteins. J. Biol. Chem. 250: 4007-4021.

Pelham, H.R.B. 1984. HSP70 accelerates the recovery of nucleolar morphology after heat shock. EMBO J. 3: 30953100 .

1985. What turns on heat shock genes? Nature 317: $477-478$.

Ringertz, N.R. and L. Bolund. 1974. The nucleus during avian erythroid differentiation. In The cell nucleus (ed. H. Busch), pp. 417-446. Academic Press, New York.

Roccheri, M.C., M.G. DiBernardo, and G. Giudice. 1981. Synthesis of heat shock proteins in developing sea urchins. Dev. Biol. 83: 173-177.

Ruiz-Vazquez, R. and A. Ruiz-Carrillo. 1982. Construction of chimeric plasmids containing histone $\mathrm{H} 5$ cDNA from hen erythrocyte DNA sequence of a fragment derived from the $5^{\prime}$ region of H5 RNA. Nucleic Acids Res. 6: 2093-2108.

Singh, M.K. and J. Yu. 1983. Accumulation of a heat shock-like protein during differentiation of human erythroid cell line K562. Nature 309: 631-633.

Small, J.V. and H.G. Davies. 1972. Erythropoesis in the yolk sac of the early chick embryo: An electron microscope and microspectrophotometric study. Tissue and Cell 4: 341-378.

Velazquez, J.M., B.J. DiDomenico, and S. Lindquist. 1980. Intracellular localization of heat shock proteins in Drosophila. Cell 20: 679-689.

Voellmy, R. and P.A. Bromley. 1982. Massive heat-shock polypeptide synthesis in late chicken embryos: Convenient system for study of protein synthesis in highly differentiated organisms. Mol. Cell. Biol. 2: 479-483.

Weintraub, H., G.L. Campbell, and H. Holtzer. 1971. Primitive 
erythropoesis in early chick embryogenesis $\mathrm{T}$ cell cycle kinetics and control of cell division. J. Cell Biol. 50: 652-668.

Weintraub, H., A. Larsen, and M. Groudine. 1981. $\alpha$-Globin gene switching during the development of chicken embryos: Expression and chromosome structure. Cell 24: 333-344.

Williams, A.F. 1972a. DNA synthesis in purified populations of avian erythroid cells. J. Cell Sci. 10: 27-46.

$1972 \mathrm{~b}$. The nature of immature avian erythrocytes in severe anemia induced by phenylhydrazine. $J$. Cell Sci. 11: 771-776.

Wu, B.J., R.E. Kingston, and R.I. Morimoto. 1986. Human HSP70 promoter contains at least two distinct regulatory domains. Proc. Natl. Acad. Sci. 83: 629-633.

Wu, B.J., G.T. Williams, R.I. Morimoto. 1987. Detection of three protein binding sites in the serum-regulated promoter of the human gene encoding the $70-\mathrm{kDa}$ heat shock protein. Proc. Natl. Acad. Sci. 84: 203-2207.

Zakeri, Z. and D.J. Wolgemuth. 1987. Developmental-stagespecific expression of the HSP70 gene family during differentation of the mammalian male germ line. Mol. Cell. Biol. 7: 1791-1796.

Zimmerman, J.L., W. Petri, and M. Meselson. 1983. Accumulation of a specific subset of $D$. melanogaster heat shock mRNAs in normal development without heat shock. Cell 32: $1161-1170$. 


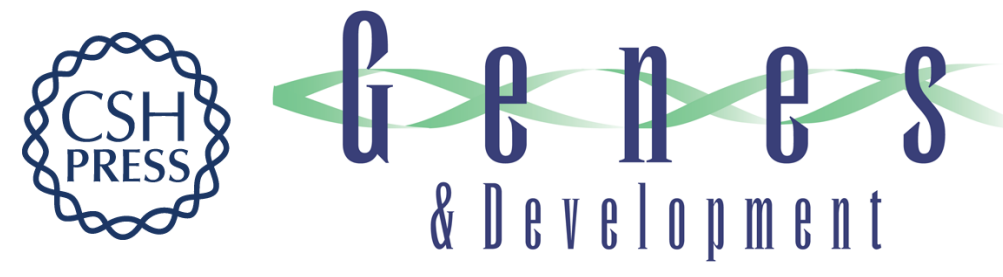

\section{Erythroid lineage-specific expression and inducibility of the major heat shock protein HSP70 during avian embryogenesis.}

S S Banerji, K Laing and R I Morimoto

Genes Dev. 1987, 1:

Access the most recent version at doi:10.1101/gad.1.9.946

References This article cites 60 articles, 24 of which can be accessed free at: http://genesdev.cshlp.org/content/1/9/946.full.html\#ref-list-1

License

Email Alerting

Receive free email alerts when new articles cite this article - sign up in the box at the top Service right corner of the article or click here.

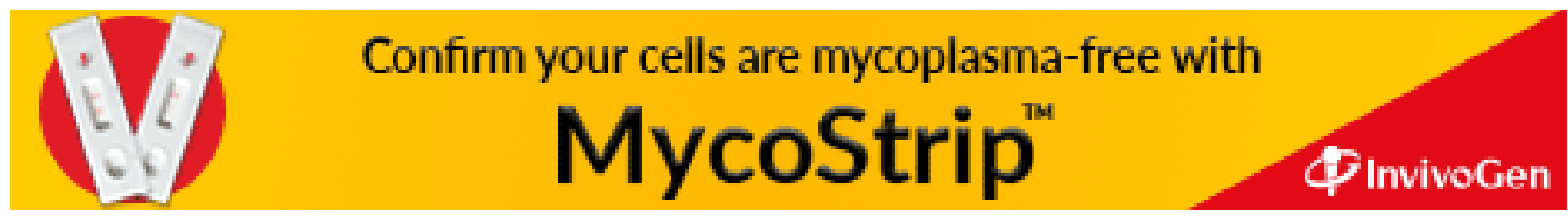

